\title{
Intake and digestibility of low and high quality forage diets by purebred and cross-bred steers of tropically adapted breeds
}

\author{
${ }^{1}$ Phillips, W. A., ${ }^{2}$ Coleman, S. W., ${ }^{3}$ Holloway, J. W., ${ }^{4}$ Riley, D. G., ${ }^{2}$ Chase, C. C., and \\ ${ }^{3}$ Warrington, $\mathrm{B}$. \\ ${ }^{1}$ USDA-ARS, Grazinglands Research Laboratory, El Reno, OK, 73036 USA \\ ${ }^{2}$ USDA-ARS, Subtropical Agricultural Research Station, Brooksville, FI 34601 USA \\ ${ }^{3}$ Texas AgriLife Research, Uvalde,TX 78801 USA \\ ${ }^{4}$ Texas A\&M University, College Station, TX 77843
}

\begin{abstract}
To improve the overall value of calves from the southern U.S. beef cow herds, tropically adapted Bos indicus and Bos taurus breeds are being evaluated. The objectives of these studies were to determine the impact of tropically adapted breed type on dry matter intake (DMI) and digestibility of low- (LQ) and high-quality (HQ) diets. In Exp. 1, steers sired by tropically adapted beef breeds (Boran, Brahman, and Tuli) had similar DM and $\mathrm{N}$ digestibility coefficients as steers sired by Gelbvieh bulls for both HQ and LQ diets. In Exp. 2, DMI of a LQ diet was increased when supplemental protein was fed at $0.4 \%$ of BW. Steers with $25 \%$ Senpol or Tuli breeding had greater DMI than steers with 25\% Brahman breeding or purebred Romosinuano steers. We concluded that previously developed concepts describing the interaction of low quality forage diets and protein supplementation is applicable to the breeds types used in this experiment. In these experiments, alternative sources of tropical adaptation in beef cattle were explored. New tropically adapted beef breeds can be incorporated into U.S. cow herds. The resulting prodigy can enter existing production systems without changing management strategies.
\end{abstract}

Keywords: Beef cattle, Feed intake, Diet digestibility, Breed type.

\section{INTRODUCTION}

The Brahman breed has been used extensively in the southern U.S. beef cattle herds to incorporate genetic adaptation to heat stress and to increase cow-calf enterprise productivity. However, when these calves are sold for finishing on high-concentrate diets in intensively managed feedlots, they are usually discounted due to poorer feedlot ADG (Phillips et al., 2001), lower marbling scores (Boyles and Riley, 1991; Phillips et al., 2001) and lower carcass quality (Sherbeck et al., 1996: Riley et al., 2003) as compared to steers with little or no Brahman breeding. The majority of the U.S. beef calves are born in winter or spring and weaned in the fall. Entry into the feedlots of the Southern Great Plains where $80 \%$ of the U.S. beef calves are fed and processed is staggered to smooth out finished beef supply. Beef calves may be used to graze annual cool-season and dormant warm-season perennial grasses as they await entry into the feedlot. This phase is referred to as a 'stocker phase' and is used to decrease the overall cost of postweaning body weight gain and to standardize health status and socialization (Peel, 2003; Phillips et al., 2004).

Using other tropically adapted beef breeds with better carcass characteristics than the Brahman in a crossbreeding programs is being investigated (Chase et. al. 2001), but data is limited on the performance of purebred and crossed-bred tropically adapted steers as stocker calves fed low- and high-quality forage diets. The objectives of these studies were to determine the impact of tropical adapted breed type on dry matter intake (DMI) and digestibility of low(LQ) and high-quality (HQ) forage diets with and without CP supplementation.

\section{MATERIALS AND METHODS}

Experiment 1: This research contributed to a multilocation long-term research project. Semen from a common source was subdivided for artificially inseminating of beef cows at research locations in Nebraska, Oklahoma, Texas, Georgia and Florida. Breed of dam varied across location and not all sire breeds were used at each location. Reports of results from each location can be found in the Symposium 
on Tropically Adapted Breed; Regional Project S1013 (Cundiff, 2005). Steers used in this experiment were born in the spring and weaned in the fall, grazed annual cool-season grasses from weaning in the fall until initiation of the digestion trials in March of the following year, when calves were approximately 12 mo old. In the first yr of the experiment, ten steer calves were selected from the cow herd at the USDAARS Grazinglands Research Laboratory, El Reno, OK ( $35^{\circ} 32^{\prime}$ latitude, $98^{\circ} 02^{\prime}$ longitude) and six steer calves from the cow herd at the Texas AgriLife Research Center, Uvalde, TX $\left(29^{\circ} 21^{\prime}\right.$ N latitude, $99^{\circ}$ 79' W longitude). Cows at both locations were either Angus or Hereford and calves were sired by the same Boran, Brahman, and Tuli bulls. In the second year of the experiment, all 16 steers were born and reared at El Reno, OK and a fourth sire-breed (Gelbvieh) was added to the experiment.

A total of four digestions trials (2 trials/yr) were conducted over a two-year period at the USDA-ARS Grazinglands Research Laboratory using a completely randomized single factor (sire breed) design. Each year, 16 steer calves representing 3 ( $\mathrm{Yr}$ 1) or $4(\mathrm{Yr} 2)$ sire breeds were used to determine the impact of sire-breed on digestion of $\mathrm{HQ}$ (Trial 1) and LQ (Trial 2) forages. Only one forage type was fed during each trial. In March of each year, steers were placed in a pen and group fed alfalfa pellets ( $\mathrm{HQ}$ forage) for $7 \mathrm{~d}$ prior to being placed in metabolism stalls designed for the separation and collection of feces and urine (Phillips and Pendulum, 1984). The amount of alfalfa pellets fed during the trial was limited to $2 \%$ of BW on an as fed basis. A 10-d adjustment period to the stalls was followed by a 7-d total fecal and urine collection period. Steers were then removed from stalls; place in a pen and given ad libitum access to mature tallgrass prairie hay (LQ forage) for $21 \mathrm{~d}$ before being returned to the same assigned metabolism stall. The two major species in the tall-grass prairie hay were little bluestem (Schizachyrium scoposium) and big bluestem (Andropogon gerardii). Another 10-d adjustment and 7-d collection period were conducted. Steers had ad libitum access to LQ diet during both the adjustment and collection periods. The LQ diet was ground with a hammer mill to reduce particle size to less than 10 $\mathrm{cm}$, but greater than $5 \mathrm{~cm}$.

Feed, orts, and fecal samples were analyzed for $\mathrm{N}$ content by the Kjeldahl method and DM content was determined by drying samples in a forced air oven at $60^{\circ} \mathrm{C}$ for $72 \mathrm{~h}$. Fiber concentration (NDF and ADF) were determined using a modified Van Soest method. In the NDF assay, triethylene glycol was substituted for ethylene glycol monoethyl ether and decahydronapthalene was omitted (Bailey and Ulyatt, 1970; Komarek et al., 1994).

Four Boran-sired steers, 6 Brahman sire-steers, and 6 Tuli-sired steers were used in $\mathrm{Yr}$ 1. In $\mathrm{Yr} 2,4$ Boran-sired, 4 Brahman-sired, 4 Tuli-sired and 4 Gelbvieh-sired steers were used. Data were combined across years and differences in digestibility of the HQ and LQ forages were determined by paired ' $\mathrm{t}$ ' test within each sire-breed group using the PROC MEANS procedure (SAS, 1999). The data were then analyzed using PROC MIXED (SAS, 1999). Year was the random term and the model used was $Y=y r$, sire-breed, and yr x sire-breed. Means are reported as Least Square Means and differences among means were determined using the Tukey's procedure as described by Steel and Torrie (1960).

Experiment 2: Eighteen steer calves were used in a switch back design to determine the effect of protein supplementation on LQ forage intake during the winter. Steers were born in the spring of 2000 at the USDA-ARS Subtropical Animal Research Station, Brooksville, FL (28 $55^{\circ} \mathrm{N}$ latitude, $\left.82^{\circ} 39\right)$. Calves were either purebred Romosinuano $(n=6)$ or Charolias-sired calves from Brahman $x$ Angus $(n=4)$, Senpol $\times$ Angus $(n=4)$, or Tuli $\times$ Angus $(n=4)$ cows. Chase et al. (2004) described the preweaning growth traits of the crossbred calves used in this study. Calves were weaned in the fall and transported to the USDA-ARS Grazinglands Research Laboratory, EI Reno, OK. After arrival calves were managed as a single group with ad libitum access to warm-season grass hay and a $14 \%$ CP mixed diet. The mixed diet was provided via a self-feeder and $\mathrm{MgO}(0.445 \%$ of diet DM) was used to limit mixed feed intake to $1.7 \%$ of BW. The combination of hay and supplemental feed was calculated to support an ADG of 0.8 to 1.0 $\mathrm{kg}$ over the next $100 \mathrm{~d}$ prior to the beginning of the experiment.

At the initiation of the experiment, calves were weighed and randomly assigned to one of 18 pens for two 21-d periods. Pens were $3.6 \mathrm{~m} \times 3.6 \mathrm{~m}$ and steers were housed inside an enclosed unheated metal building. Wood shavings were used to keep the pens dry and fecal material was removed daily. Steers had ad libitum access to mature tallgrass prairie hay in a feeder and water in another container. The hay fed in this experiment was mature tall-grass prairie hay harvested in square bales of approximately $25 \mathrm{~kg} / \mathrm{bale}$ and stored in a hay barn until needed. The two major species in this tall-grass 
prairie hay were little bluestem (Schizachyrium scoposium) and big bluestem (Andropogon gerardii). Prior to feeding, hay was ground through a hammer mill to reduce particle size to less than $10 \mathrm{~cm}$, but greater than $5 \mathrm{~cm}$. Hay was weighed and added to the feeder each morning at 0800 to insure ad libitum access to LQ forage. Orts were collected twice weekly. Hay fed, supplement fed and orts were sampled and DM concentration was determined as described in Experiment 1.

Steers were randomly assigned within breed type to CONTROL (no supplement) or SUPPLEMENTED (20\% CP supplement fed at $0.4 \%$ of BW) treatments for the first 21-d period. Supplemental CP (20\% Breeder Cubes, Evergreen Feeds, El Reno, OK) was fed in a separate container once daily. Steers were allowed $14 \mathrm{~d}$ to adapt to the assigned diet before determining hay intake over a 7-d period. Steers were then switched to the opposite treatment for the second 21-d period (14-d preliminary period followed by a 7-d intake period) in a switch back design. Body weights were recorded on Tuesday and Fridays of each week throughout the experiment at $1000 \mathrm{~h}$. Linear regression was used to calculate ADG within each 21-d period.

Dry matter content of hay, supplement, and orts samples was determined by drying in a forced air oven at $65^{\circ} \mathrm{C}$ for $72 \mathrm{~h}$. Samples of hay, CP supplement and orts were analyzed for $\mathrm{N}$ concentration by using a complete-combustion $\mathrm{N}$ analyzer (Leco CHN-1000, Leco Corp., St. Joseph, $\mathrm{MO})$ and NDF and ADF concentration was determined as described in Experiment 1. Initially, data were analyzed using a paired ' $\mathrm{t}$ ' test to determine the impact of supplementation on DMI. Subsequently, data were analyzed again using the GLM procedure (SAS Inst., Cary, NC) with animal as the experimental unit. The model used was $Y=$ breed, diet and breed $X$ diet. No significant interactions were observed and data were then sorted by diet (control or supplemented) and the model $\mathrm{Y}=$ breed was used and the following contrasts were made; 1 ) purebred Romosinuano vs cross-bred steers, 2) $25 \%$ Brahaman steers vs $25 \%$ Senpol $+25 \%$ Tuli, and 3) $25 \%$ Senpol vs $25 \%$ Tuli. Means are reported as least squares means.

After the hay intake experiment was completed (March 22), calves were removed from their pens and managed as a single group during a 71-d stocker phase. Calves grazed wheat pasture for $36 \mathrm{~d}$ followed by tall-grass native prairie for $35 \mathrm{~d}$. For the finishing phase, calves were blocked by breed type and randomly assigned within breed type to one of two bermudagrass pastures at a stocking density of 9 calves/ha. When available forage in the pasture was decreased to $1000 \mathrm{~kg} \mathrm{DM} / \mathrm{ha}$ as determined by visual observation, a self-feeder was placed in each pasture. The diet in the self-feeder contained $4.5 \%$ molasses, $3.5 \%$ cottonseed meal, $0.75 \%$ limestone, $82.5 \%$ cracked corn, $8 \%$ alfalfa, and $0.75 \%$ urea. The diet was formulated to contain $13.2 \% \mathrm{CP}, 2.06$ Mcal $/ \mathrm{kg} \mathrm{NE}, 1.35 \mathrm{Mcal} / \mathrm{kg} \mathrm{NE}_{\mathrm{g}}, 35 \mathrm{mg} / \mathrm{kg}$ of monensin (Rumensin, Elanco Animal Health, Indianapolis, IN) and $11.5 \mathrm{mg} / \mathrm{kg}$ of tylosin (Tylan, Elanco Animal Health, Indianapolis, IN). Before entering the finishing phase, calves were treated for internal parasites (Ivomec Plus, Merial, Rathway, NJ) and were implanted with $36 \mathrm{mg}$ of zeronal (Ralgro, Schering-Plough Animal Health, Union, NJ). Calves were considered finished when fat thickness over the $12^{\text {th }}$ to $13^{\text {th }}$ rib was equal to or greater than $10 \mathrm{~mm}$, which was determined by experienced personnel.

Data collected during the stocker and finishing phases were analyzed using a GLM procedure (SAS Inst., Cary, NC) and contrasts were made for ADG between the purebred Romosinuano steers and the cross-bred steers as described earlier. Animal was used as the experimental unit. Means among breed types were separated using the least significant difference procedure (Steel and Torrie, 1960).

\section{RESULTS}

Experiment 1 - Intake and digestibility: Mean BW of steers used in this experiment was $286 \pm 11.5 \mathrm{~kg}$ and was not different $(P>0.10)$ among sired breeds. The nutrient content of $L Q$ and $H Q$ hay fed in Experiment 1 are shown in Table 1 . By design the $\mathrm{HQ}$ diet had more CP and less NDF and ADF than the LQ diet. The amount of HQ diet offered was limited to $2 \%$ (as fed) of $\mathrm{BW}$ and as a result no differences $(P>0.10)$ were observed for DMI of HQ diet among the sire breeds (Table 2). In contrast, steers had ad libitum access to LQ diet and Boransired steers consumed less $(P<0.05)$ of the LQ diet than the other three breed groups (Table 2).

Table 1. Nutrient content of low-quality (LQ-hay and High-Quality (HQ-hay) hay fed in Experiment 1 and hay and supplement fed in Experiment 2, \% DM basis

\begin{tabular}{|l|l|l|l|l|}
\hline \multirow{2}{*}{ Item } & \multicolumn{2}{|c|}{ Experiment 1 } & \multicolumn{2}{c|}{ Experiment 2 } \\
\cline { 2 - 5 } & LQ-hay & HQ-hay & Hay & Supplement \\
\hline CP & 5.0 & 19.0 & 5.6 & 24.6 \\
\hline NDF & 72.7 & 45.9 & 70.8 & \\
\hline
\end{tabular}




\begin{tabular}{|l|l|l|l|l|}
\hline ADF & 48.6 & 26.7 & 46.0 & 14.8 \\
\hline
\end{tabular}

Digestion coefficients for the DM and $\mathrm{N}$ components in the HQ diet were greater $(P<0.01)$ than those observed for the LQ diet. Digestibility coefficients for $H Q$ and $L Q$ diets were not different $(P>0.10)$ among sired-breeds (Table 2). Because DMI of the HQ diet was limited to $2 \%$ (as fed) of BW, the amount of $\mathrm{N}$ consumed $(\mathrm{g} / \mathrm{d})$ was not different $(P=0.26)$ among the three breed-types (mean $=152 \mathrm{~g} / \mathrm{d} \pm 4.8$ ). Nitrogen digestion coefficients (673 g/kg DM \pm 10.4) was not different $(P=0.44)$ among the Boran-, Brahman- and Tuli-sired steers when the HQ diet was fed. When the LQ diet was fed the amount of $\mathrm{N}$ consumed was $1 / 3$ of that observed when $\mathrm{HQ}$ diet was fed to these same steers (30 vs $152 \mathrm{~g} / \mathrm{d}$ ) and the amount of $N$ consumed $(\mathrm{g} / \mathrm{d})$ was not different $(\mathrm{P}=$ 0.18) among the three breed-types.

Table 2. Dry matter intake (DMI) and digestibility coefficients (g/kg) of high quality (alfalfa pellets) and low quality (mature tall grass prairie hay) forage diets fed to steers sired by Boran (BO), Brahman (BR), Gelvieh (GE) and Tuli (TU) bulls from Hereford and Angus dams (Exp. 1).

\begin{tabular}{|l|c|c|c|c|c|}
\hline \multirow{2}{*}{} & \multicolumn{4}{|c|}{ Sire breed } \\
\cline { 2 - 6 } & BO & BR & GE & TU & SE \\
\hline DMI g/kg BW & & & & 74.7 & 2.0 \\
\hline High quality diet & 72.1 & 76.5 & 76.9 & $74.0^{x}$ & 3.2 \\
\hline Low quality diet & $67.2^{y}$ & $76.1^{x}$ & & 557 & 11.9 \\
\hline DM digestibility, g/kg & & & 570 & 420 & 17.7 \\
\hline High quality diet & 554 & 561 & 426 & & \\
\hline Low quality diet & 422 & 417 & & 661 & 14.1 \\
\hline N digestibility, g/kg; & & & 665 & 226 & 49.8 \\
\hline High quality diet & 658 & 268 & 250 & 191 & \\
\hline Low quality diet & & & & \\
\hline
\end{tabular}

${ }^{x y}$ Means in the same row with different superscripts differ, $\left.\mathrm{P}<0.05\right)$.

From these data, we concluded that under a management strategy where a HQ forage diet is limitfed at $2 \%$ of BW, Boran-, Brahman- and Tuli-sired steers will have similar DM and $\mathrm{N}$ digestibility coefficients and that performance differences could be the result of nutrient utilization for maintenance and growth.

Experiment 2 - Protein supplementation: Nutrient content of the hay and supplement fed in Experiment 2 are shown in Table 1 . The nutrient content of the hay fed in this experiment was similar to the LQ diet used in Experiment1 (Table 1). At the beginning of the first 21-d period, average BW was $288 \pm 6.6 \mathrm{~kg}$ and was not different $(P>0.10)$ among the four breed-types. Hay DMI increased $(P<0.01)$ from 69.4 $\mathrm{g} / \mathrm{kg} \mathrm{BW}^{0.75}$ to $78.3 \mathrm{~g} / \mathrm{kg} \mathrm{BW}^{0.75}$ when supplemental protein was fed and ADG increased $(P<0.01)$ from 0.01 to $0.95 \mathrm{~kg}$ (Table 3). If no supplemental CP was fed, forage DMI was similar to that observed for steers fed the LQ diet in Experiment 1. Regardless of the diet fed, purebred Romosinuano (RR) and CBA steers consumed less $(P<0.05)$ hay than CSA and CTA steers (Table 3). However, ADG was not different $(P>0.10)$ among breed-groups when hay was fed alone or with a $20 \%$ CP supplement. The addition of supplemental $\mathrm{CP}$ to the diet increased forage DMI by $19 \%$ for the CBA steers, by $13 \%$ for the RR steers and $11 \%$ and $7 \%$ for CSA and CTA steers, respectively. Purebred Romosinuano and CBA steers were apparently more efficient than CSA and CTA steers in converting LQ diet to gain, because they consumed less DM but have similar ADG. 
Table 3. Forage DMI, total DMI, and ADG of purebred Romosinuano (RR) and Charolias-sired calves from Brahman $x$ Angus (CBA), Senpol $X$ Angus (CSA), and Tuli $x$ Angus (CTA) dams fed ground hay without (Control diet) and with (Supplemented diet) $20 \%$ CP supplement fed at $0.4 \%$ BW once daily in a switch back design (Exp.2).

\begin{tabular}{|l|c|c|c|c|c|}
\hline & \multicolumn{4}{|c|}{ Breed type } \\
\hline & RR & CBA & CSA & CTA & SE \\
\hline Forage DMI, g/kg BW $^{0.75}$ & & & & & \\
\hline Control diet $^{\text {ab }}$ & 65.5 & 63.1 & 75.8 & 76.2 & 3.6 \\
\hline Supplemented diet $^{\mathrm{b}}$ & 74.1 & 75.3 & 84.1 & 81.3 & 3.4 \\
\hline Total DMI, g/kg BW $^{0.15}$ & & & & & \\
\hline Control diet $^{\text {ab }}$ & 65.5 & 63.1 & 75.8 & 76.2 & 3.6 \\
\hline Supplemented diet & 91.4 & 91.3 & 99.4 & 97.6 & 3.5 \\
\hline ADG, kg/day & & & & & 0.11 \\
\hline Control diet & 0.20 & -0.15 & 0.11 & -0.03 & 0.12 \\
\hline Supplemented diet & 0.98 & 1.09 & 0.86 & 0.79 & 0.12 \\
\hline
\end{tabular}

${ }^{a}$ Contrast RR vs. CBA + CSA + CTA, P $<0.05$.

${ }^{b}$ Contrast CBA vs CSA + CTA, $\mathrm{P}<0.05$.

During the stocker phase, initial and final BW was not different among breed-types, but purebred Romosinuano steers had a lower $(P<0.10)$ ADG than CBA or CTA steers (Table 4). During the pasture-finishing phase, purebred Romosinuano steers had greater $(P<0.10)$ ADG than crossbred

steers (Table 4). During the first $38 \mathrm{~d}$ of the finishing period steers were consuming supplemental feed and had an ADG of $1.52 \mathrm{~kg} \pm 0.17$. This ADG was not different $(P=0.68)$ among breed-type. Purebred Romosinuano steers had greater $(P<0.10)$ ADG during the pasture finishing period than cross-bred steers. Differences in carcass characteristics were not determined in this experiment.

Table 4. Performance of purebred Romosinuano (RR), and Charolias sired steers from Brahman $x$ Angus (CBA), Senpol $X$ Angus (CSA) and Tuli X Angus (CTA) dams during the stocker and finishing phases (Exp. 2).

\begin{tabular}{|l|c|c|c|c|c|}
\hline & \multicolumn{5}{|c|}{ Breed type } \\
\hline Item & RR & CBA & CSA & CTA & SE \\
\hline Stocker phase & & & & & 6.5 \\
\hline Initial BW, kg & 308 & 316 & 309 & $0.84^{\mathrm{y}}$ & 0.07 \\
\hline ADG, kg & $0.62^{\mathrm{x}}$ & $0.85^{\mathrm{y}}$ & $0.77^{\mathrm{xy}}$ & & 10 \\
\hline Finishing phase & & & & 356 & 0.06 \\
\hline Initial BW, kg & 351 & 376 & 364 & $1.14^{\mathrm{y}}$ & 10 \\
\hline ADG, kg/day & $1.36^{\mathrm{x}}$ & $1.14^{\mathrm{y}}$ & $1.22^{\mathrm{y}}$ & 155 & \\
\hline Days on feed & 137 & 137 & 142 & & 10 \\
\hline
\end{tabular}

\footnotetext{
${ }^{\mathrm{xy}}$ Means in the same row with different superscripts differ, $\mathrm{P}<0.10$.
}

From these data, we concluded that purebred RR steers and crossbred steers that contained $25 \%$ tropically adapted breeding responded to CP supplementation in a similar manner and that 
nutritional management strategies developed for temperate breeds are applicable to the breed-types used in this study. When dietary nutrient density is low, RR steers will have decreased ADG compared to crossbred steers. However, when dietary nutrient density is high the RR steers have great ADG. Purebred Romosinuano may have smaller intestinal tracts and less internal organ weight, which lowers maintenance requirements and increases, feed efficiency.

\section{DISCUSSION}

Digestibility of diets: Low quality forages contains low concentrations of CP and digestible DM and lack adequate amounts of rumen degradable protein to stimulate ruminal microbial activity, which lessens digestibility and reduces DMI (Hannah el at., 1991). Concentration of CP, NDF and ADF in the hays used in Exp. 1 and 2 were similar to previous reports (Bodine et al., 2001; Sanson and Clanton, 1989; Olson et al.,1999). Olson et al. (1999) and Heldt et al. (1999) reported that 45 to $50 \%$ of the CP in mature native prairie hay was degradable in the rumen. Although the $\mathrm{CP}$ in the mature prairie hay used in these experiments was not fractionated into ruminal degradable and undegradable fractions, we hypothesized that the low concentrations of $\mathrm{CP}$ and degradable CP in the hay used in Exp. 1 and 2 probably limited ruminal microbial growth, reduced ruminal DM turnover and DMI. The low $\mathrm{N}$ digestion coefficient observed in Exp. 1 for the LQ diet reflects the unavailability of the dietary $\mathrm{CP}$ fraction for rumen microorganism growth.

Chemical composition of diets: Chemical composition of the HQ diet (Alfalfa pellets) used in Exp. 1 was similar to values reported by Merchen and Satter (1983) and Amos et al. (1984) and digestion coefficients were similar to previous reports (Am0s et al., 1984; Merchen and Satter, 1983; Sutton and Velter, 1970). Because the HQ diet contained a higher concentration of $\mathrm{CP}$ and DIP and a lower concentration of NDF and ADF, it was more digestible than the LQ diet.

Tropical adapted breeds: Tropical adapted breed of cattle evolved under different forage and environmental conditions than the temperate breeds. Therefore, tropically adapted breed should differ in digestive kinetics and nutrient utilization as compared to temperate breeds (Moore et al., 1975; Beaver et al., 1989). Boran is a Zebu breed (Bos indicus) that evolved in southern Ethiopia, while Tuli is a Sangatype cattle developed in Zimbabiwe, but the Tuli breed is considered to be Bos taurus. Gelvieh is a continental breed (Bos taurus) and is used as a terminal sire-breed to increase pre- and post-weaning calf performance (Tinker at al., 1988; Arango et al., 2002). The Boran, Tuli and Brahman breeds were selected and evolved under a hot, humid environment where forage quality was low, while the Gelvieh was developed within a temperate environment with relatively greater quality forages.

Boran and Tuli are two tropically adapted breeds that have been shown to be more heat tolerant than Herefords, Hereford X Boran, and Hereford X Tuli steers and were as heat tolerant as Hereford $X$ Brahman steers (Gaughan et al., 1999). Boran and Brahman cattle increase sweating rate to dissipate heat, but the Tuli uses a decrease in metabolic heat production to accommodate high thermal heat index (THI; Gaughan et al). Because Exp. 1 was conducted during late winter and early spring, we assumed that the steers were not subjected to heat stress. Therefore, any differences in DMI of $\mathrm{LQ}$ forage and digestibility of both $\mathrm{HQ}$ and $\mathrm{LQ}$ forages observed in this experiment would have been due to metabolic and physiologic differences among the breed types (Ferrell and Jenkins, 1998).

No differences were observed for DM and $\mathrm{N}$ digestibility of the LQ or HQ diet among the breed combinations used in this study. In our experiment, Brahman-sired steers consumed $14 \%$ more digestible DM (DMI X DM digestible coefficient) than Boran-sired steers, while Gelvieh- and Tuli-sired steers were intermediate. Brahman-sired steers may utilize LQ diets more efficiently than Bos taurus breeds, because they produce more saliva, are better at recycling $\mathrm{N}$, and have a different microbial population that can digest fiber more efficiently (Moore et al., 1975). Crossing tropical adapted breeds with temperate beef breeds results in an animal that has similar heat tolerance as the purebred tropical breed, but increased growth rate due to heterosis (Gaughan et al., 1999; Phillips et al., 2004; Solis et al., 1988).

Crude protein supplementation of low quality diet: In Exp. 2, providing additional CP increased DMI and ADG by increasing rumen degradable protein (RDP) concentration of the diet and likely resulted in increased rumen microbial growth (Olson et al., 1999). When hay was fed alone, overall DMI was similar to those observed in Experiment 1 and was similar to previous reports (Heldt et al., 1999; Sanson et al., 1989; Olson et al., 1999). As noted in this experiment, these researchers also reported an 
increase in DMI when dietary $\mathrm{CP}$ and DIP concentration was increased. Bodine et al. (2001) concluded that DIP intake should be equal to $10 \%$ of the daily digestible OM intake. In Exp. 2, providing supplemental CP at $0.4 \%$ of the steers BW increased the dietary DIP concentration to approximately $10 \%$ of the digestible OM intake and resulted in an increase in DMI and ADG. McCollum and Horn (1990) and Hutson et al. (2002) provided reviews of supplementing grazing livestock under a wide range of management strategies. McCollum and Horn (1990) focused their review on protein supplementation of grazing livestock. The concepts, mechanisms, and principles they outlined were observed in the present experiments using beef breed previously unavailable for testing. In the review by Hutson et al. (2002) focused on production systems across Texas and included supplementation strategies for mature cows, developing heifers, stocker calves and cow-calf pairs. The observations from the present experiments fall within the concepts outlined by Hutson et al. (2002). Therefore, we conclude that previously developed concepts of the impact of forage quality and protein supplementation on DM intake and digestibility are applicable to the breed types used in these experiments.

Voluntary DM intake: Voluntary DMI (VDMI) of forage based diets by ruminants is limited by digesta flow, rate of digestion and digestive tract capacity (Allen, 1996). Providing access to supplemental dietary CP can increase rate of digestion and digesta flow and result in an increase in VDMI. In Exp. 2, RR steers and CBA steers had similar rates of VDMI with and without CP supplementation and VDMI was less than observed for CSA and CTA steers. These differences may be due to differences in digestive tract size. In the feedlot phase, RR steers had greater ADG than the crossbreed steers. We hypothesized that RR steers had smaller tracts than the crossbred steers, which decrease maintenance cost and increase the amount of energy available for ADG. Smaller digestion tract is only advantageous when dietary energy balance controls VDMI and not distention.

Performance of Romosinuano steers: Romosinuano is a Criollo type, red-brown, polled non-Bos indicus breed that is native to Columbia (Hammond et al., 1996). Under temperate production environment, purebred Romosinuano steers had decreased ADG during the winter grazing period, but produced leaner carcasses than purebred Angus steers during the finishing phase (Phillips et al.,
2006). In Exp. 2, ADG during the stocker period was less for RR steers than the $25 \%$ tropically adapted breeds. This agrees with previous observations at this laboratory (Phillips et al., 2006). It appears from these data and other reports that a $25 \%$ reduction in ADG during the stocker period is anticipated for calves that are purebred Romosinuano as compared to purebred Angus and 25\% tropical adapted breeds. However, in both the present and previous study, Romosinuano steers performed well during the finishing phase. Phillips et al. (2006) reported that Romosinuano steers produced carcasses with greater Longissmus muscles area, and dressing percentage, but lesser marbling score, quality grade, fat thickness and yield grade compared to Angus steers.

\section{CONCLUSION:}

New tropically adapted beef breeds can be incorporated into cow herds located in the humid regions of the southern US to increase productivity, climate adaptation, and quality of the calf. Calves produced by these herds are typically moved to more temperate environments for growth and development and may be exposed to low ambient temperatures, diets with low concentrations of $\mathrm{CP}$, and fed small amounts of supplemental CP to stimulate DM intake. The results of the present study revealed that previously developed concepts describing the interaction of low quality forage diets and protein supplementation is applicable to the breeds types used in this experiment and new tropical adapted breeds can be added to existing production systems without dramatically changing management strategies.

\section{REFERENCE}

Allen, M. S. (1996). Physical constraints on voluntary intake of forages by ruminants. J. Anim. Sci. 74:3063-3075.

Amos, H. E., Windham, W.R., and Evans, J. J. (1984). Nitrogen metabolism of steers fed sun cured hay and drum dehydrated alfalfa and coastal bermudagrass. J. Anim. Sci. 58:987-995.

Arango, J. A., Cundiff, L. V., and VanVleck, L.D. (2002). Comparisons of Angus-, Chianina-, Hereford-, Gelbvieh-, Maine Anjou-, and Red Poll-sired cows for weight, weight adjusted for body condition score, height, and body condition score. J. Anim. Sci. 80:3133-3141.

Bailey, R. W., and Ulyatt, M. J. (1970). Pasture quality and ruminant nutrition. II. Carbohydrate and lignin composition of detergent-extracted residues from 
pasture grasses and legumes. N.Z. J. Agric. Res. 13:591-598.

Beaver, E. E., Williams, J. E., Miller, S. J., Hancock, D. L , Hannah, S. M., and O'Connor, D. L. (1989). Influence of breed and diet on growth, nutrient digestibility, body composition and plasma hormones of Brangus and Angus steers. J. Anim. Sci. 67:2415-2425.

Boyles, S. L., Caton, J. S., and Sime, D. M. (1998). Influence of soybean meal or increasing levels of barley supplementation on intake, ruminal fermentation, site of digestion, in situ forage degradability, and duodenal amino acid flow in steers fed bromegrass hay. Prof. Anim Sci. 14:118-126.

Boyles. S. C. and Riley, J. G. (1991). Feedlot performance of Brahman x Angus versus Angus steers during cold weather. J. Anim. Sci. 69:2677-2684.

Bodine, T. N., Purvis, II, H. T., and Lalman, D. L. (2001). Effects of supplementation type on animal performance, forage intake, digestion, and ruminal measurements of growing beef cattle. J. Anim. Sci. 79:1041-1051.

Chase, C. C., Jr., Chenoweth, P. J., Lawson, R. R., Hammond, A. C., Olson, T. A., West, R. L., and Johnson, D. R. (2001). Growth, puberty, and carcass characteristics of Brahman-, Senepol-, and Tuli-sired F1 Angus bulls. J. Anim. Sci. 79:2006-2015.

Chase, C. C., Jr., Riley, D. G., Olson, T. A., Coleman, S. W., and Hammond, A. C. (2004). Maternal and reproductive performance of Brahman $x$ Angus, Senepol $x$ Angus and Tuli $x$ Angus cows in the subtropics. J. Anim. Sci. 82:2764 - 2772.

Cundiff, L. V. (2005). Performance of tropically adapted breeds in a temperate environment: Calving, growth, reproduction and maternal traits. $P$. 123-135. Proceeding: Symposium on tropically adapted breeds. Regional Project S-1013. Little Rock, AR.

Ferrell, C. L. and Jenkins, T.G. (1998). Body composition and energy utilization by steers of diverse genotypes fed a high-concentrate diet during the finishing period: II. Angus, Boran, Brahman, Hereford, and Tuli sires. J. Anim. Sci. 76:647-657.

Gaughan, J. B., Mader, T. L., Holt, S. M., Josey, M. J., and Rowan K. J. (1999). Heat tolerance of Boran and Tuli crossbred steers. J. Anim. Sci. 77:2398-2405.

Hammond, A. C., Olson, T. A., Chase, Jr., C. C., Bowers, E. J., Randel, R. D., Murphy, C. N., Vogt, D. W., and Tewolde A. (1996). Heat tolerance in two tropically adapted Bos taurus breeds , Senepol, and Romosinuano, compared with Brahman, Angus, and Hereford cattle in Florida. J. Anim. Sci. 74:295-303.

Hannah, S. M., Cochran, R. C., Vanzant, E. S., and Harmon. D. L. (1991). Influence of protein supplementation on site and extent of digestion, forage intake, and nutrient flow characteristics on steers consuming dormant bluestem-range forage. J. Anim. Sci. 69:2624-2633.

Heldt, J. S., Cochran, R. C., Stokka, G. L., Farmer, C. G., Mathis, C. P., Titgemeyer, E. C., and Nagaraja. T. G. (1999). Effects of different supplemental sugars and starch fed in combination with degradable intake protein on low-quality forage use by beef steers. J. Anim. Sci. 77:2793-2802.

Hutson, J. E., Rouquette, Jr., F. M., Ellis, W. C., Lippke, H., and Forbes. T. D. A. (2002). Supplementation of grazing beef cattle. TM-12. Texas Agric. Exp. Stat. College Station.

Komarek. A. R. 1(994). A comparison of methods for determining ADF using the filter bag technique versus conventional filtration. J. Anim. Sci. 72(Suppl. 1):114.

McCollum, F. T., and Horn, G. W. (1990). Protein supplementation of grazing livestock: A review. Prof. Anim. Sci. 6:1-16.

Merchen, N. R. and Satter. L. D. (1983). Digestion of nitrogen by lambs fed alfalfa conserved as baled hay or as low moisture silage. J. Anim. Sci. 56:943-951.

Moore, R. L., Essig, H. W., and Smithson, L. J. (1975). Influence of breed of beef cattle on ration utilization. J. Anim. Sci. 41:203-207.

Olson, K.C., Cochran, R. C., Jones, T. J., Vanzant, E. S., Titgemeyer, E. C., and Johnson, D. E. (1999). Effects of ruminal administration of supplemental degradable intake protein and starch on utilization of low-quality warm-season grass hay by beef steers. J. Anim. Sci. 77:1016-1025.

Peel, D. S. (2003). Beef cattle growing and backgrounding programs. Vet. Clin. Food Anim. 19:365-385.

Phillips, W. A., Brown, M. A., Brown, Jr., A. H., and Coleman. S. W. (2001). Genotype X environment interaction for postweaning performance in crossbred calves grazing winter wheat pasture or dormant native prairie. J. Anim. Sci. 79:1370-1377.

Phillips, W. A, Brown, M. A., Holloway, J. W., and Warrington, B. (2004). Influence of live weight gain during the winter grazing period on subsequent grazing and feedlot performance. Prof. Anim. Sci. 20:401-412.

Phillips, W. A., Coleman, S. W., Riley, D. G., Chase, Jr., C. C., and Mayeux H. S. (2006). Stocker and feedlot performance and carcass characteristics of purebred Angus and Romosinuano steers. Prof. Anim. Sci. 22:813.

Phillips, W. A., and Pendlum, L. C. (1984). Digestibility of wheat and alfalfa silage with and without wheat straw. J. Anim. Sci. 59:476-482. 
Riley, D. G., Chase, Jr., C. C., Hammond, A. C., West, R. L., Johnson, D. D., Olson, T. A., and Coleman S. W. (2003). Estimated genetic parameters for palatability traits of steaks from Brahman cattle. J. Anim. Sci. 81:54-60.

Sanson, D. W. and Clanton, D. C. (1989). Intake and digestibility of low-quality meadow hay by cattle receiving various levels of whole shell corn. J. Anim. Sci. 67:2854-2862.

Sherbeck, J. A., Tatum, J. D., Field, T. G., Morgan, J. B., and Smith. G. C. (1996). Effect of phenotypic expression of Brahman breeding on marbling and tenderness traits. J. Anim. Sci. 74:304-309.
Steel, R. G. D. and Torrie. J. H. (1960). Principles and Procedures of Statistics. McGraw-Hill Book Co. New York.

Sutton, A. L., and Vetter R. L. (1971). Nitrogen studies with lambs fed alfalfa (Medicago Sativa) as hay, lowmoisture and high moisture silages. J. Anim. Sci. 32:1256 -1261.

Solis, J. C., Byers, F. M., Schelling, G. T., Long, C. R., and Greene L. W. (1988). Maintenance requirements and energetic efficiency of cows of different breed types. J. Anim. Sci. 66:764-773.

Tinker, E. D., Frahm, R. R., and Buchanan, D. S. (1988). Comparison of Gelvieh and Limousin sires in a terminal crossbreeding system. J. Anim. Sci. 66:1355362. 